\title{
PRECLINICAL IN VIVO MODELS OF FRACTURE-RELATED INFECTION: A SYSTEMATIC REVIEW AND CRITICAL APPRAISAL
}

\author{
N. Vanvelk ${ }^{1}$, M. Morgenstern'르, T.F. Moriarty ${ }^{3}$, R.G. Richards ${ }^{3}$, S. Nijs ${ }^{1,4}$ and WJ. Metsemakers ${ }^{1,4, *}$ \\ ${ }^{1}$ Department of Trauma Surgery, University Hospitals Leuven, Belgium \\ ${ }^{2}$ Department of Orthopaedic Surgery and Traumatology, University Hospital of Basel, Switzerland \\ ${ }^{3} \mathrm{AO}$ Research Institute Davos, Switzerland \\ ${ }^{4}$ KU Leuven-University of Leuven, Department Development and Regeneration, B-3000 Leuven, Belgium
}

\begin{abstract}
A fracture-related infection (FRI) is an important complication that can lead to an increase in morbidity, mortality and economic costs. Preclinical in vivo models are critical in the evaluation of novel prevention and treatment strategies, yet it is important that these studies recapitulate the features of an FRI that make it such a clinical challenge. The aim of this systematic review was to survey the available preclinical models of FRIs and assess which of the key FRI-specific parameters are incorporated in these models.

A comprehensive search was performed on July $1^{\text {st }} 2017$ in PubMed, Embase and Web of Science. Overall, 75 preclinical studies were identified, $97.3 \%(n=73)$ of which use Staphylococcus aureus as the causative microorganism. The most common mode for creation of bone instability is an osteotomy $(n=30 ; 40 \%)$, followed by the creation of a defect $(n=26 ; 34.7 \%)$. An actual fracture is created in only 19 studies $(25.3 \%)$. $12(16 \%)$ of the models include a time gap between bacterial inoculation and fixation to mimic the time-totreatment in clinical open fracture scenarios.

This systematic review reveals that animal models used in translational research on prevention and treatment of FRIs rarely incorporate all key clinical features in one model and that there is an overrepresentation of $S$. aureus in comparison to actual clinical epidemiology. To improve the relevance of these studies, existing preclinical models should be adapted or new models developed that better recapitulate the clinical condition of an FRI.
\end{abstract}

Keywords: Preclinical in vivo models, animal models, fracture-related infection, fracture fixation, systematic review, Staphylococcus aureus, open fracture, soft tissue damage.

${ }^{*}$ Corresponding author: Willem-Jan Metsemakers, Department of Trauma Surgery, University Hospitals Leuven, Leuven, Belgium.

Telephone number: +32 16344277 Email: willem-jan.metsemakers@uzleuven.be

Copyright policy: This article is distributed in accordance with Creative Commons Attribution Licence (http://creativecommons.org/licenses/by-sa/4.0/).

\section{Introduction}

Fracture-related infections (FRIs) are among the most important complications after fracture fixation (Reizner et al., 2014). The cause of this complication is often multifactorial, with the risk of infection being significantly higher, for example, in cases of an open fracture, severe soft tissue damage and polytrauma patients (Kortram et al., 2017). Internal fixation of closed fractures has a relatively low infection incidence of 1-2 \%, whilst the incidence after the operative treatment of open fractures can rise to $30 \%$ (Boxma et al., 1996; Ktistakis et al., 2014; Papakostidis et al., 2011). An FRI can negatively affect the clinical outcome due to delayed healing, functional impairment or even amputation of the affected limb (Metsemakers et al., 2018a). FRIs also lead to prolonged hospital stays, increased morbidity and mortality and are associated with higher healthcare and overall economic costs in comparison to non-infected equivalents (Olesen et al., 2017).

Due to the negative impact of FRIs on the clinical outcome, and the associated socio-economic impact, a large amount of research is performed to optimise prevention and treatment strategies for FRIs (Metsemakers et al., 2018a). Conducting clinical trials of FRIs in human subjects is a challenge due to the low infection incidence, the heterogeneity of the 
musculoskeletal trauma population, the multiplicity of treatment options and the broad range of possible causative bacteria (Reizner et al., 2014). Therefore, preclinical in vivo models can serve as a critical control point prior to clinical application of any new diagnostic procedure or intervention, offering a controlled environment without many of the variables inherent in a patient population. To provide a robust evaluation of any intervention aiming to simulate an FRI, the chosen model should ideally recapitulate the clinical condition (Brown et al., 2014). This includes a fracture creation, soft tissue damage, contamination with bacteria, and, when mimicking an open fracture situation, a delay in treatment (i.e. debridement and surgical fixation several hours after the traumatic incident).

The aim of the present systematic review was to survey the range and critical features of preclinical in vivo models used in FRI studies. The hypothesis was that these models only rarely include these key FRI factors.

\section{Materials and Methods}

All relevant aspects of the Cochrane Handbook for Interventional Systematic Reviews (Higgins and Green, 2011) were followed and the study was written according to the Preferred Reporting Items for Systematic Reviews and Meta-Analyses (PRISMA) statement (Moher et al., 2010).

\section{Search strategy}

A comprehensive search was performed on July $1^{\text {st }}$ 2017 in PubMed, Embase and Web of Science. With the help of a biomedical information specialist, a set of search strings were composed for each database. Overall, 1,208 references were collected in Mendeley (Mendeley desktop version 1.17.11, Elsevier). After the exclusion of duplicates, 995 articles were retained. These were screened by two reviewers (NV and MM). In case the two reviewers did not reach consent, a third reviewer (WJM) was consulted.

The search process is summarised in Fig. 1. During the first phase, titles and abstracts were reviewed. Irrelevant articles were excluded and 170 relevant articles were retained for full text review. After review of the full text of the remaining articles, 75 eligible articles were included in the present review.

\section{Inclusion/exclusion criteria}

Inclusion criteria were (1) preclinical in vivo models, (2) presence of bony instability (a fracture/osteotomy/ defect) of long bones, (3) local inoculation of the
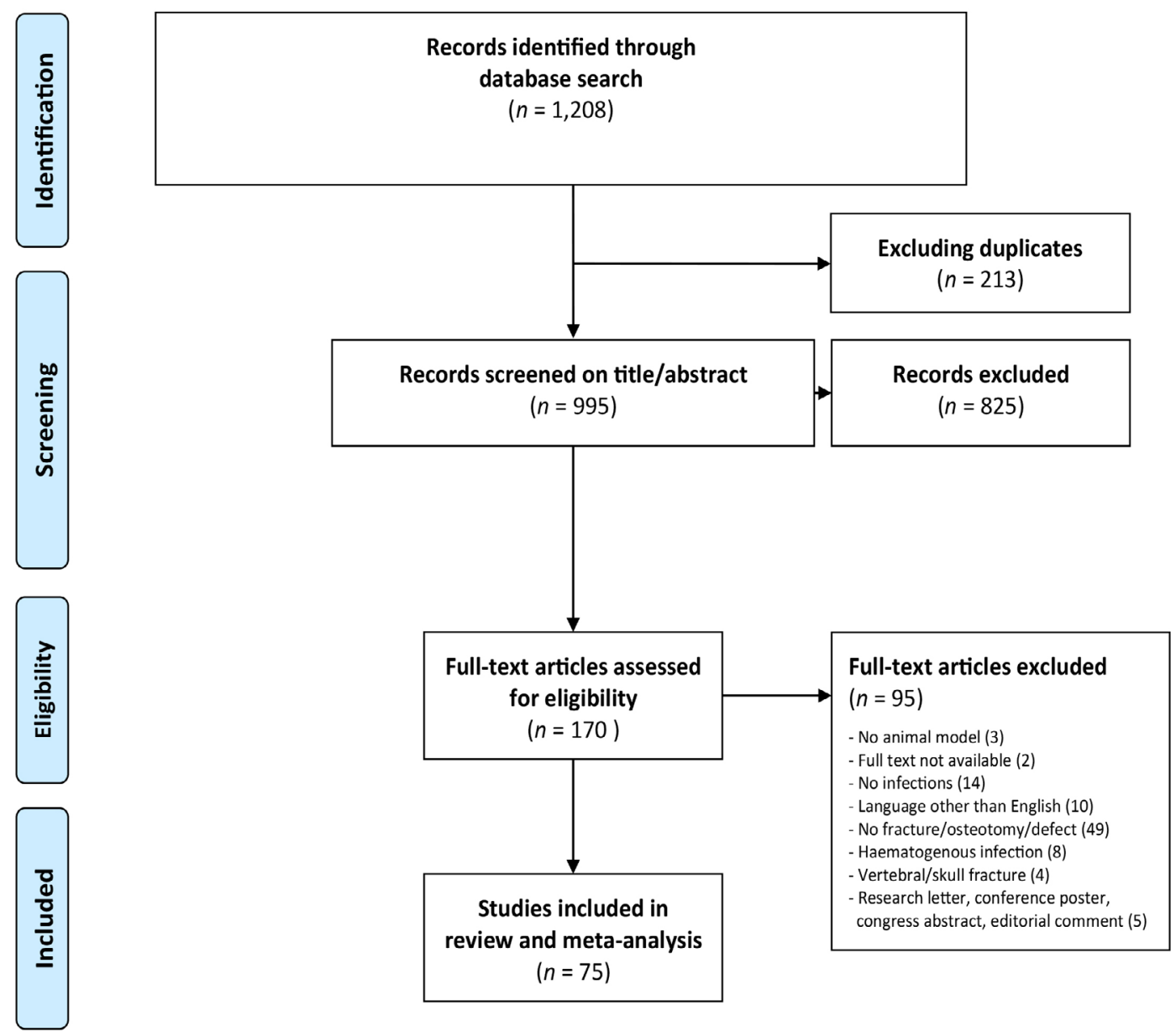

Fig. 1. Outline of the search and selection process including exclusions and final count of acceptable manuscripts. 
fracture with a pathogen. For inclusion all three criteria had to be met. Exclusion criteria included (1) cadaver studies, (2) haematogenous infection, (3) fracture models of the vertebrae or skull, (4) articles published before 01.01.1970. Published abstracts, conference posters, letters and articles in any language other than English were excluded.

\section{Data extraction and critical appraisal}

The extraction of data was performed by two reviewers (NV and MM). To study the hypothesis, data on pathogen species, strain name and inoculum [colony forming unit (CFU)-count] used were collected. In addition, data on animal species, location of the fracture/osteotomy/defect, method of creation of bony instability and type of fixation were collected. Furthermore, details on soft tissue damage were included. For wounds left open after inoculation with the pathogen, the model was classified as open. For the wounds closed immediately after addition of the bacteria, the model was labelled as closed. Lastly, the articles were grouped into five categories based on the study objective: model description, prevention, treatment, bone healing and pathogenesis. A study with the primary aim of developing a new model that closely resembles the clinical setting of an FRI was classified as model description. Prevention and treatment studies both test the effect of new interventions on infection and the line between these two types of studies is not always perfectly clear. Thus, classification was largely based on the objective, as reported by the authors. For the most part, in preventive studies, the intervention happens at the same time as the fracture fixation. In treatment studies, the tested intervention is mostly performed after an infection is allowed to develop over a certain time. Studies with the primary objective of studying the infection influence on bone healing or evaluating new strategies to improve callus formation in infected fractures were assigned to the bone healing group. Studies with the primary aim of investigating the microorganisms' characteristics (e.g. intracellular survival) and the fracture environment (e.g. increased perfusion of infected fractures) were labelled as pathogenesis. These studies also examined different patterns of infection and osteolysis.

\section{Results}

\section{Study objective}

Articles were categorised into five groups (model description, prevention study, treatment study, bone healing study and model on the pathogenesis of an FRI), based on the objective of the research (Table 1). Eleven $(14.7 \%)$ studies describe a new model that could later be utilised for future research on FRIs. Treatment modalities are tested in thirteen $(17.3 \%)$ studies. In twenty-nine (38.7\%) studies, methods to prevent infection development are tested. In nine (12\%) studies, the effect of infection on bone healing is researched or new methods to improve bone healing after infection are examined. Five (6.7\%) articles provide information on the pathogenesis of the FRI. Eight (10.7\%) articles have a combination of study objectives (Table 1).

\section{Animal species}

Eight different animal species are mentioned in the studies (Table 2-4). Over half of the research is performed on rats $(n=38 ; 50.7 \%)$. Twenty-two $(29.3 \%)$ studies performed tests on rabbits; all but one study (Azi et al., 2012) use New-Zealand white rabbits. Five $(6.7 \%)$ studies include mice, three $(4 \%)$ dogs, three ( $4 \%$ ) sheep, two (2.7\%) goats, one $(1.3 \%)$ pigs and one $(1.3 \%)$ Guinea pigs.

\section{Anatomical location}

An overview of the anatomical locations of instability creation is provided in Table 2-4. In most of the included models, fractures, osteotomies or osseous defects are created in the lower $\operatorname{limb}(n=65 ; 86.7 \%)$, with relatively fewer utilising the upper $\operatorname{limb}(n=10$; $13.3 \%)$. The anatomical area of choice is the femur in thirty-nine studies (52\%), the tibia in twenty-five $(33.3 \%)$, tibia and fibula in one $(1.3 \%)$, the humerus in three $(4 \%)$, the radius in five $(6.7 \%)$ and the ulna in two $(2.7 \%)$.

\section{Model type}

According to the previously mentioned definition, most models simulate a closed fracture situation $(n=63 ; 84 \%)$, whereas only twelve (16\%) studies mimic an open fracture by introducing a time gap between inoculation and fixation (Table 2-4).

Bone instability is applied by creating a fracture, an osteotomy or a defect. In nineteen (25.3\%) models (Table 2), a real fracture is created. In most of the studies, this is established by using a specially designed device, in which a weight is dropped on the bone, causing a fracture that can be reproduced multiple times. Failure of this technique is mentioned only once: Boyce et al. (2012) report the exclusion of one animal because of a comminuted fracture not fixable with their implant system. Hill and Watkins (2001) describe a model in which a fracture is created by firing a steel fragment at the tibia. In the model of Petri and Schaberg (1984), a fracture is created by using a rongeur. In thirty (40\%) models, a single osteotomy is performed to mimic a fracture (Table $3)$. A defect is created in twenty-six (34.7\%) models mostly by performing a double osteotomy (Table 4).

It is reasonable to assume that, if the aforementioned fracture devices would produce enough force to create a fracture, they would also cause soft tissue damage. The same reasoning was applied to the ballistic fracture of Hill and Watkins (2001). Petri and Schaberg (1984) mention creating soft tissue damage with a haemostat. This way, soft tissue damage is 
Table 1. Study objectives.

\begin{tabular}{|c|c|c|c|}
\hline \multicolumn{2}{|c|}{ Objective of research } & $\begin{array}{l}\text { Number of } \\
\text { articles }\end{array}$ & References \\
\hline \multicolumn{2}{|c|}{ Model description } & 11 & $\begin{array}{l}\text { Alt et al., 2011; Andriole et al., 1973; Arens et al., 2015; Azi } \\
\text { et al., 2012; Chen et al., 2005; Helbig et al., 2015; Inzana } \\
\text { et al., 2015; Passl et al., 1984; Robinson et al., 2011; Windolf } \\
\text { et al., 2013; Worlock et al., 1988b }\end{array}$ \\
\hline \multicolumn{2}{|c|}{ Treatment } & 13 & $\begin{array}{l}\text { Bi et al., 2007; Brown et al., 2000; Brown et al., 2014; Hamel } \\
\text { et al., 2008; Huang et al., 2013; Khodaparast et al., 2003; Li } \\
\text { et al., 2010a; Lubis et al., 2005; Penn-Barwell et al., 2014b; } \\
\text { Petri and Schaberg, 1984; Rand et al., 2015; Sanchez et al., } \\
\text { 2013; Sener et al., } 2010\end{array}$ \\
\hline \multicolumn{2}{|c|}{ Prevention } & 29 & $\begin{array}{l}\text { Ter Boo et al., 2016; Boyce et al., 2012; Costa et al., 2016; } \\
\text { Darouiche et al., 1998; Fei et al., 2010; Hill et al., 2002; Hill } \\
\text { and Watkins, 2001; Jacob et al., 1993; Jacob et al., 1997; Lesic } \\
\text { et al., 2004; Li et al., 2009; Li et al., 2010; Lindsey } \\
\text { et al., 2010a; Lovati } \text { et al., 2016a; Metsemakers et al., 2016; } \\
\text { Penn-Barwell et al.,2012a; Penn-Barwell et al., 2012b; Penn- } \\
\text { Barwell et al., 2015; Schaer et al., 2012; Sethi et al., 2015; } \\
\text { Stewart et al., 2010; Stewart et al., 2012; Tennent et al., 2016; } \\
\text { Windolf et al., 2014; Worlock et al., 1994; Xiao et al., 2015; } \\
\text { Xie et al., 2009; Zheng et al., 2010; Zhou et al., 2017 }\end{array}$ \\
\hline \multicolumn{2}{|c|}{ Bone healing } & 9 & $\begin{array}{l}\text { Bilgili et al., 2015; Brick et al., 2009; Chen et al., 2002; Chen } \\
\text { et al., 2006; Chen et al., 2007; Deng et al., 2013; Lovati et al., } \\
\text { 2016; Schindeler et al., 2015; Southwood et al., 2004 }\end{array}$ \\
\hline \multicolumn{2}{|c|}{ Pathogenesis } & 5 & $\begin{array}{l}\text { De Mesy Bentley et al., 2016; Gilbert et al., 2015; Hamza } \\
\text { et al., 2012; Rochford et al., 2016; Seebach et al., } 2015\end{array}$ \\
\hline \multirow{6}{*}{ Combination } & $\begin{array}{l}\text { Model and } \\
\text { pathogenesis }\end{array}$ & 1 & Lindsey et al., 2010 \\
\hline & $\begin{array}{l}\text { Model and } \\
\text { prevention }\end{array}$ & 2 & Evans et al., 1993; Penn-Barwell et al., 2014 \\
\hline & $\begin{array}{l}\text { Prevention and } \\
\text { treatment }\end{array}$ & 1 & Worlock et al., 1988 \\
\hline & $\begin{array}{l}\text { Prevention and } \\
\text { pathogenesis }\end{array}$ & 1 & Curtis et al., 1995 \\
\hline & $\begin{array}{l}\text { Prevention and } \\
\text { bone healing }\end{array}$ & 2 & Prinz et al., 2017; Tran et al., 2013 \\
\hline & $\begin{array}{c}\text { Treatment and } \\
\text { bone healing }\end{array}$ & 1 & Guelcher et al., 2011 \\
\hline
\end{tabular}

present in the same nineteen $(25.3 \%)$ studies that include the creation of a real fracture. None of the defect/osteotomy studies report creating additional soft tissue damage, beyond damage that is caused by the surgical dissection and creation of the defect/ osteotomy.

In thirty-five $(46.7 \%)$ studies osteosynthesis is achieved with a plate. Polyacetyl $(n=10 ; 28.6 \%)$ (Brick et al., 2009; Brown et al., 2014; Chen et al., 2002; Chen et al., 2005; Chen et al., 2006; Chen et al., 2007; Guelcher et al., 2011; Li et al., 2010a; Sanchez et al., 2013; Tennent et al., 2016), titanium ( $n=7 ; 20 \%)$ (Metsemakers et al., 2016; Rochford et al., 2016; Stewart et al., 2012; Windolf et al., 2013; Windolf et al., 2014; Xiao et al., 2015; Xie et al., 2009) and polyoxymethylene $(n=6$; $17.1 \%$ ) (Penn-Barwell et al., 2012a; Penn-Barwell et al., 2012b; Penn-Barwell et al., 2014a; Penn-Barwell et al., 2014b; Penn-Barwell et al., 2015; Rand et al., 2015) are the most used materials. In thirty (40\%) models, the fracture is stabilised with an intramedullary nail. In two of these, external fixation is performed in addition to intramedullary fixation (Curtis et al., 1995; Hamel et al., 2008). In small animals (rabbits and rats), k-wires serve as intramedullary fixation devices ( $n=19 ; 63.3 \%$ ) (Bilgili et al., 2015; Boyce et al., 2012; Darouiche et al., 1998; Gilbert et al., 2015; Hamel et al., 2008; Hamza et al., 2012; Helbig et al., 2015; Lesic et al., 2004; Li et al., 2009; Li et al., 2010; Lindsey et al., 2010a; Lindsey et al., 2010b; Prinz et al., 2017; Sener et al., 2010; Stewart et al., 2010; Worlock et al., 1988a; Worlock et al., 1988b; Worlock et al., 1994; Zhou et al., 2017). In two studies, both plate fixation and intramedullary fixation are used, although not in the same animal (Arens et al., 2015; Worlock et al., 1994). Evans et al. (1993) describe a model in which stability is achieved by means of screw 
Table 2. Type of bone instability: fractures.

\begin{tabular}{|c|c|c|c|c|c|c|}
\hline $\begin{array}{c}\text { Closed/ } \\
\text { open }\end{array}$ & Animal & Location & Implant & Pathogen & Strain & Reference \\
\hline \multirow{14}{*}{ Closed } & \multirow{3}{*}{ Dog } & Ulna & None & $\begin{array}{l}\text { S. aureus } \\
\text { P. aeruginosa }\end{array}$ & $\begin{array}{l}\text { Washington } \\
\text { hospital strain } \\
\text { PA } 220\end{array}$ & $\begin{array}{c}\text { Petri and Schaberg, } \\
1984\end{array}$ \\
\hline & & \multirow[b]{2}{*}{ Tibia } & \multirow[b]{2}{*}{ Intramedullary } & \multirow[b]{2}{*}{ S. aureus } & \multirow[b]{2}{*}{ ATCC12692 } & Brown et al., 2000 \\
\hline & & & & & & $\begin{array}{l}\text { Khodaparast et al., } \\
2003\end{array}$ \\
\hline & Pig & Tibia & None & S. aureus & ATCC29213 & $\begin{array}{l}\text { Hill and Watkins, } \\
2001\end{array}$ \\
\hline & \multirow{4}{*}{ Rabbit } & \multirow{4}{*}{ Tibia } & \multirow[t]{3}{*}{ Intramedullary } & \multirow{4}{*}{ S. aureus } & $\begin{array}{l}\text { Giorgio strain } \\
\text { and phage type } \\
80-81\end{array}$ & Andriole et al., 1973 \\
\hline & & & & & \multirow{3}{*}{ Phage type 29} & Worlock et al., 1988a \\
\hline & & & & & & Worlock et al., 1988b \\
\hline & & & $\begin{array}{c}\text { Plate or } \\
\text { intramedullary }\end{array}$ & & & Worlock et al., 1994 \\
\hline & \multirow{6}{*}{ Rat } & \multirow{5}{*}{ Femur } & \multirow{6}{*}{ Intramedullary } & \multirow{3}{*}{ S. aureus } & $\begin{array}{c}\text { UFMG } \\
\text { central lab }\end{array}$ & Costa et al., 2016 \\
\hline & & & & & Clinical isolate & Robinson et al., 2011 \\
\hline & & & & & Not specified & Hamza et al., 2012 \\
\hline & & & & $\begin{array}{l}\text { S. aureus } \\
\text { E. coli }\end{array}$ & $\begin{array}{l}\text { ATCC } 49230 \\
\text { ATCC } 25922\end{array}$ & Stewart et al., 2010 \\
\hline & & & & $\begin{array}{l}\text { MRSA } \\
\text { A. Baumannii }\end{array}$ & $\begin{array}{l}\text { UAB 05-197 } \\
\text { AC4795 }\end{array}$ & Gilbert et al., 2015 \\
\hline & & $\begin{array}{l}\text { Tibia } \\
\text { and } \\
\text { fibula }\end{array}$ & & S. aureus & ATCC 49230 & Helbig et al., 2015 \\
\hline \multirow{5}{*}{ Open } & \multirow{5}{*}{ Rat } & \multirow{5}{*}{ Femur } & \multirow{5}{*}{ Intramedullary } & \multirow{5}{*}{ S. aureus } & \multirow{4}{*}{ Clinical isolate } & Li et al., 2010 \\
\hline & & & & & & Lindsey et al., 2010 \\
\hline & & & & & & Lindsey et al., 2010a \\
\hline & & & & & & Boyce et al., 2012 \\
\hline & & & & & Not specified & Li et al., 2009 \\
\hline
\end{tabular}

osteosynthesis. In seven models, no osteosynthesis is performed (Azi et al., 2012; Bi et al., 2007; Deng et al., 2013; Hill and Watkins, 2001; Huang et al., 2013; Lubis et al., 2005; Petri and Schaberg, 1984). In these models, surrounding muscles provide sufficient stability or an external cast is applied.

Only five $(6.4 \%)$ articles display models that combines these three features of FRI: creation of a fracture, inclusion of soft tissue damage and a time gap between bacterial inoculation and treatment of the fracture. These models use the same general setup: Sprague-Dawley rats are anaesthetised, the hind leg is shaved and a fracture of the femur is created using a custom-made device. In two out of five articles a weight is dropped from a height of $153 \mathrm{~mm}$ producing an estimated force of $104.8 \mathrm{~N}$ ( $\mathrm{Li}$ et al., 2009; Lindsey et al., 2010b). For the remaining three models, this information is not provided (Boyce et al., 2012; Li et al., 2010b; Lindsey et al., 2010c). After fracture creation, the leg is prepped for surgery and an incision on the dorsolateral surface of the femur is made. The rats are inoculated with $100 \mu \mathrm{L}$ of a bacterial suspension containing $10^{2} / 0.1 \mathrm{~mL}$ Staphylococcus aureus (S. aureus). The fracture is left open for $1 \mathrm{~h}$. Lastly, the fracture is stabilised by an intramedullary k-wire, the wound closed and the anaesthesia ended.

\section{Pathogen characteristics}

Fig. 2 displays the distribution of pathogens used in the included articles. A large majority $(n=69 ; 92 \%)$ of the included models are inoculated with S. aureus as the single infection-causing pathogen. In two of these, a methicillin-resistant $S$. aureus (MRSA) strain is used (Hamel et al., 2008; Xiao et al., 2015). S. aureus is administered as an intracellular inoculum inside the osteoblasts in one study (Hamza et al., 2012). ATCC 25923 (Fei et al., 2010; Prinz et al., 2017; Schaer et al., 2012; Sener et al., 2010; Southwood et al., 2004; Stewart et al., 2012; Tran et al., 2013; Xie et al., 2009; Zhou et al., 2017) and Xenogen 36 (Guelcher et al., 2011; Inzana et al., 2015; Li et al., 2010a; Penn-Barwell et al., 2012a; Penn-Barwell et al., 2012b; Penn-Barwell et al., 2014a; Penn-Barwell et al., 2014b; Penn-Barwell 
Table 3. Type of bone instability: osteotomies.

\begin{tabular}{|c|c|c|c|c|c|c|}
\hline Closed/open & Animal & Location & Implant & Pathogen & Strain & Article \\
\hline \multirow{27}{*}{ Closed } & \multirow[b]{2}{*}{ Goat } & \multirow[b]{2}{*}{ Tibia } & \multirow[b]{2}{*}{ Intramedullary } & \multirow[b]{2}{*}{ S. aureus } & ATCC25923 & Tran et al., 2013 \\
\hline & & & & & ATCC29213 & $\begin{array}{c}\text { Curtis et al., } \\
1995\end{array}$ \\
\hline & Guinea Pig & Femur & Intramedullary & $\begin{array}{l}\text { S. aureus } \\
\text { E. coli }\end{array}$ & $\begin{array}{l}\text { Not specified } \\
\text { ATCC } 0111 \text { B4 }\end{array}$ & Passl et al., 1984 \\
\hline & \multirow{5}{*}{ Mouse } & \multirow{5}{*}{ Femur } & \multirow{5}{*}{ Plate } & \multirow{5}{*}{ S. aureus } & \multirow{2}{*}{ ATCC29213 } & $\begin{array}{l}\text { Windolf et al., } \\
2014\end{array}$ \\
\hline & & & & & & $\begin{array}{l}\text { Windolf et al., } \\
2013\end{array}$ \\
\hline & & & & & JAR060131 & $\begin{array}{l}\text { Rochford et al., } \\
2016\end{array}$ \\
\hline & & & & & $\begin{array}{l}\text { UAMS-1, GFP+ } \\
\text { UAMS-1, protein } \\
\text { A deficient } \\
\text { mutant of UAMS- } \\
\text { 1, USA300LAC }\end{array}$ & $\begin{array}{c}\text { De Mesy } \\
\text { Bentley et al., } \\
2016\end{array}$ \\
\hline & & & & & Xen 36 & $\begin{array}{c}\text { Inzana et al., } \\
2015\end{array}$ \\
\hline & \multirow{9}{*}{ Rabbit } & \multirow{3}{*}{ Humerus } & & \multirow{3}{*}{ S. aureus } & \multirow{3}{*}{ JAR060131 } & $\begin{array}{l}\text { Metsemakers } \\
\text { et al., } 2016\end{array}$ \\
\hline & & & Plate & & & $\begin{array}{l}\text { Ter Boo et al., } \\
2016\end{array}$ \\
\hline & & & $\begin{array}{c}\text { Plate or } \\
\text { intramedullary }\end{array}$ & & & $\begin{array}{l}\text { Arens et al., } \\
2015\end{array}$ \\
\hline & & \multirow{6}{*}{ Tibia } & \multirow{6}{*}{ Intramedullary } & \multirow{5}{*}{ S. aureus } & \multirow{4}{*}{ ATCC25923 } & $\begin{array}{c}\text { Zhou et al., } \\
2017 \\
\end{array}$ \\
\hline & & & & & & $\begin{array}{c}\text { Prinz et al., } \\
2017\end{array}$ \\
\hline & & & & & & Fei et al., 2010 \\
\hline & & & & & & Xie et al., 2009 \\
\hline & & & & & Newman & $\begin{array}{l}\text { Darouiche } \\
\text { et al., } 1998\end{array}$ \\
\hline & & & & MRSA & Not specified & Xiao et al., 2015 \\
\hline & \multirow{8}{*}{ Rat } & \multirow{4}{*}{ Femur } & \multirow{2}{*}{ Intramedullary } & \multirow{2}{*}{ S. aureus } & ATCC12600 & $\begin{array}{l}\text { Schindeler } \\
\text { et al., } 2015\end{array}$ \\
\hline & & & & & Clinical isolate & $\begin{array}{l}\text { Bilgili et al., } \\
2015\end{array}$ \\
\hline & & & Plate & MRSF & COI1153754-03-14 & $\begin{array}{c}\text { Lovati et al., } \\
2016\end{array}$ \\
\hline & & & ride & NINSE & GU11100/34-00-14 & $\begin{array}{c}\text { Lovati et al., } \\
2016 a\end{array}$ \\
\hline & & \multirow{4}{*}{ Tibia } & \multirow{4}{*}{ Intramedullary } & \multirow{4}{*}{ S. aureus } & ATCC 25923 & $\begin{array}{c}\text { Sener et al., } \\
2010 \\
\end{array}$ \\
\hline & & & & & ATCC6538P & Lesic et al., 2004 \\
\hline & & & & & EDCC 5055 & Alt et al., 2011 \\
\hline & & & & & EDCC5035 & Sethi et al., 2015 \\
\hline & \multirow{2}{*}{ Sheep } & \multirow{2}{*}{ Tibia } & \multirow{2}{*}{ Plate } & \multirow{2}{*}{ S. aureus } & \multirow{2}{*}{ ATCC25923 } & $\begin{array}{l}\text { Schaer et al., } \\
2012\end{array}$ \\
\hline & & & & & & $\begin{array}{c}\text { Stewart et al., } \\
2012\end{array}$ \\
\hline & Rabbit & Tibia & Plate & S aureys & ATCC 27660 & $\begin{array}{c}\text { Jacob et al., } \\
1993 \\
\end{array}$ \\
\hline Open & Navit & Iivid & Thate & S. unteus & AfC- 27000 & $\begin{array}{c}\text { Jacob et al., } \\
1997 \\
\end{array}$ \\
\hline & Sheep & Tibia & Intramedullary & S. aureus & ATCC29213 & Hill et al., 2002 \\
\hline
\end{tabular}


Table 4. Type of bone instability: defects.

\begin{tabular}{|c|c|c|c|c|c|c|}
\hline Closed/open & Animal & Location & Implant & Pathogen & Strain & Article \\
\hline \multirow{22}{*}{ Closed } & \multirow{4}{*}{ Rabbit } & \multirow{2}{*}{ Radius } & Screws & \multirow{3}{*}{ S. aureus } & $\begin{array}{l}\text { ATCC25923 } \\
\text { ATCC49230 }\end{array}$ & $\begin{array}{c}\text { Evans et al., } \\
1993\end{array}$ \\
\hline & & & None & & ATCC 6538 & $\begin{array}{c}\text { Lubis et al., } \\
2005 \\
\end{array}$ \\
\hline & & Ulna & None & & Not specified & Azi et al., 2012 \\
\hline & & Tibia & Intramedullary & MRSA & Clinical isolate & $\begin{array}{c}\text { Hamel et al., } \\
2008\end{array}$ \\
\hline & \multirow{18}{*}{ Rat } & \multirow{18}{*}{ Femur } & \multirow{18}{*}{ Plate } & \multirow{18}{*}{ S. aureus } & ATCC25923 & $\begin{array}{l}\text { Southwood } \\
\text { et al., } 2004\end{array}$ \\
\hline & & & & & Mu50 & $\begin{array}{c}\text { Zheng et al., } \\
2010\end{array}$ \\
\hline & & & & & UAMS-1 & $\begin{array}{c}\text { Tennent et al., } \\
2016 \\
\end{array}$ \\
\hline & & & & & $\begin{array}{c}\text { UAMS-1, } \\
\text { ATCC49230 }\end{array}$ & $\begin{array}{c}\text { Seebach et al., } \\
2015\end{array}$ \\
\hline & & & & & $\begin{array}{c}4 \text { clinical } \\
\text { strains, UAMS- } \\
1 \text { ATCC49230, } \\
\text { Xen36 } \\
\text { ATCC49525 }\end{array}$ & $\begin{array}{c}\text { Sanchez et al., } \\
2013\end{array}$ \\
\hline & & & & & \multirow{8}{*}{ Xen 36} & Li et al., 2010 \\
\hline & & & & & & Rand et al., 2015 \\
\hline & & & & & & $\begin{array}{l}\text { Guelcher et al., } \\
2011\end{array}$ \\
\hline & & & & & & $\begin{array}{c}\text { Penn-Barwell } \\
\text { et al., 2012a }\end{array}$ \\
\hline & & & & & & $\begin{array}{l}\text { Penn-Barwell } \\
\text { et al., 2012b }\end{array}$ \\
\hline & & & & & & $\begin{array}{c}\text { Penn-Barwell } \\
\text { et al., 2014a }\end{array}$ \\
\hline & & & & & & $\begin{array}{l}\text { Penn-Barwell } \\
\text { et al., 2014b }\end{array}$ \\
\hline & & & & & & $\begin{array}{l}\text { Penn-Barwell } \\
\text { et al., } 2015\end{array}$ \\
\hline & & & & & \multirow{2}{*}{ Clinical isolate } & Chen et al., 2002 \\
\hline & & & & & & Chen et al., 2005 \\
\hline & & & & & \multirow{3}{*}{ Not specified } & Chen et al., 2006 \\
\hline & & & & & & Chen et al., 2007 \\
\hline & & & & & & Brick et al., 2009 \\
\hline \multirow{4}{*}{ Open } & \multirow{3}{*}{ Rabbit } & \multirow{3}{*}{ Radius } & \multirow{3}{*}{ None } & \multirow{3}{*}{ S. aureus } & \multirow[t]{2}{*}{ ATCC 28923} & $\begin{array}{c}\text { Huang et al., } \\
2013\end{array}$ \\
\hline & & & & & & Bi et al., 2007 \\
\hline & & & & & Not specified & Deng et al., 2013 \\
\hline & Rat & Femur & Plate & S. aureus & Not specified & $\begin{array}{c}\text { Brown et al., } \\
2014\end{array}$ \\
\hline
\end{tabular}

et al., 2015; Rand et al., 2015) are the most commonly used strains $(n=9 ; 13 \%)$. ATCC 29213 is utilised in five (7.2 \%) studies (Curtis et al., 1995; Hill et al., 2002; Hill and Watkins, 2001; Windolf et al., 2013; Windolf et al., 2014). In nine (13\%) animal models, a clinically isolated strain of S. aureus is introduced. The clinical strains are isolated from patients with chronic osteomyelitis (Boyce et al., 2012), infected prosthesis (Chen et al., 2005; Robinson et al., 2011), infected wound (Li et al., 2010b; Lindsey et al., 2010b; Lindsey et al., 2010c), intra-articular infections (Bilgili et al., 2015) or blood (Hamel et al., 2008). In one study, the clinical source is not specified (Chen et al., 2002). Other strains and multi-strain models are mentioned in less than five $(7.2 \%)$ studies each. Nine articles $(13 \%)$ do not specify the strain or source of $S$. aureus 
used in their setup (Azi et al., 2012; Brick et al., 2009; Brown et al., 2014; Chen et al., 2006; Chen et al., 2007; Deng et al., 2013; Hamza et al., 2012; Li et al., 2009; Xiao et al., 2015).

Four $(5.3 \%)$ models use a combination of S. aureus and another pathogen. The combination of $S$. aureus with Escherichia coli (E. coli) is described twice (Passl et al., 1984; Stewart et al., 2010). Although, only in one of these studies a polymicrobial inoculum was used (Stewart et al., 2010). The other two studies combine S. aureus with Acinetobacter baumannii (A. baumannii) (Gilbert et al., 2015) or Pseudomonas aeruginosa (P. aeruginosa) (Petri et al., 1984) in the same inoculum.

Including both inoculation alone or in combination with a second pathogen, $S$. aureus was used in 73 out of $75(97.3 \%)$ studies. Three models are inoculated with other species. Two use methicillin-resistant Staphylococcus epidermidis (S. epidermidis) (MRSE; strain GOI1153754-03-14) (Lovati et al., 2016a; Lovati et al., 2016b) and one use E. coli (Passl et al., 1984).

Inoculation is accomplished in several different ways, e.g. the pathogen is applied to the collagen (Rand et al., 2015), directly to the implant (Rochford et al., 2016) or injected using a saline solution (Lovati et al., 2016b).

\section{Discussion}

A substantial amount of research is conducted aiming to improve our knowledge on FRIs and to develop novel interventional strategies to reduce the incidence and improve treatment outcome. New prevention and treatment concepts for human patients require preclinical testing, which includes animal studies. The model used need to be in line with current clinical problems (Brown et al., 2014). Although the models of orthopaedic implant infection are reviewed by Calabro et al. (2013) and Reizner et al. (2014), to the best of our knowledge, this is the first systematic review of its kind focusing solely on FRIs.

The hypothesis of the present study was that preclinical in vivo models only rarely mimic the real clinical situation and do not include key factors such
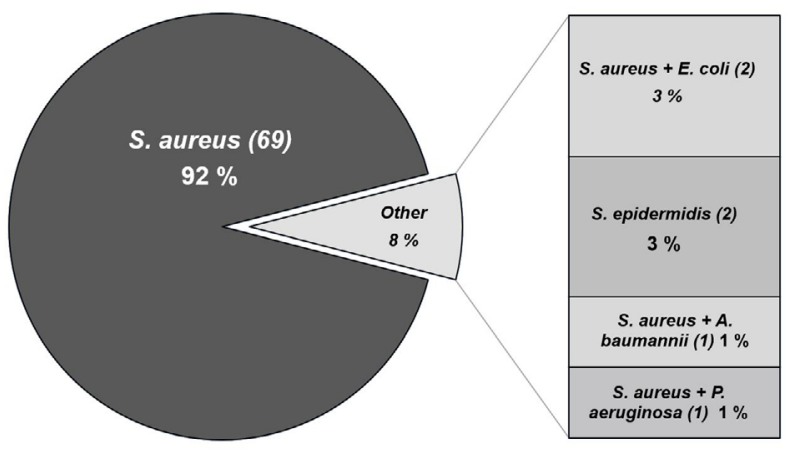

Fig. 2. Distribution of pathogens in preclinical models of FRIs. as delay before treatment, presence of a fracture, soft tissue damage and diversity of causative pathogens.

\section{Animal species}

Most of the studies are performed using small animals such as rats, rabbits, mice and guinea pigs $(n=66 ; 88 \%)$. Thus, large animals such as dogs, sheep, goats and pigs are only described in nine experimental setups (12\%) (Table 2,3 ). To the best of our knowledge, there is currently no evidence on the effect of the animal choice on the study validity. However, it seems rational to base the choice of animal on the study objective. Large animals could be favoured in case of biomechanical studies, while small animals (e.g. rodents) are more suitable for the investigation of molecular mechanisms and genetics of bone healing (Auer et al., 2007). Another element to keep in mind when selecting the animal species is the availability of the specific tools needed to produce some of the key characteristics of an FRI. Such tools are currently primarily available for mice, rats, rabbits and sheep. Since the inclusion of specific key factors of an FRI will likely have a bigger impact on the validity of the study than the selection of the animal, it makes sense to opt for one of these species, if possible.

Finally, utilising large animals could involve problems such as increased cost, additional space requirement and reduced availability of molecular biology tools in comparison with smaller animal (e.g. rodent) models.

\section{Anatomical location}

Most studies are performed using the lower limb ( $n=65 ; 86.7 \%$ ). Instability is created in the upper limb in the remaining ten models (13.3\%) (Table $2-4)$. There is currently a lack of evidence suggesting one anatomical location is favoured over the others, however, the objective of the study should be kept in mind. For generic research on FRIs, the anatomical location will be of lesser importance. Although, when the research question is closely linked to soft tissue injury/coverage, this should be considered when choosing the optimal anatomical location.

\section{Delay before treatment}

In most models ( $n=63 ; 84 \%$ ) (Table $2-4)$ the wound is closed immediately after the inoculation of the pathogen. This approach is not congruent with the clinical setting, because often a time gap exists between the occurrence of an open fracture, for example, and treatment commencing (e.g. transport to the hospital, diagnostic examinations). Current guidelines recommend fracture irrigation and debridement within the first $6 \mathrm{~h}$ after admittance. In the models described as open, the delay-totreatment is as little as $30 \mathrm{~min}$. The influence of this time gap on infection rates is debated. Srour et al. (2015) demonstrate in a prospective study that the time to irrigation and debridement does not increase 
infection rates, provided it is performed within $24 \mathrm{~h}$ following the injury. In daily practice, these results could lead to even longer time lapses between the trauma and initial surgery (i.e. debridement and fixation), making the gap between clinical reality and translational research even bigger. Furthermore, in cases of chronic/late-onset FRI (i.e. fistulae), time to definitive treatment and concomitant soft tissue coverage is often even longer. Therefore, it seems imperative that future in vivo models take these time windows into account when developing new prevention and treatment technologies. Of course, the inclusion of a delay-to-treatment will also entail a risk for certain disadvantages. Increasing the time gap might increase variability in the infection (i.e. development of polymicrobial infections), which is compatible with the clinical setting, but the disadvantage would be to have a less controllable environment with respect to the infecting pathogens. Furthermore, it might also entail a longer anaesthesia time and, therefore, a greater burden on the animal.

\section{Instability and fixation method}

The second observation was that within the included studies, bony instability is often created by an osteotomy or a defect (double osteotomy). Although creating a real fracture is far more realistic, this method is only found in $25.3 \%(n=19)$ of the studies (Table 2). In these models, a fracture is mostly created using a device that drops a weight onto the bone. Compared to a clinical situation, fracture stability will be more difficult to achieve in case of a fracture as compared to a controlled osteotomy, which is often performed after the osteosynthesis. A fracture may be multi-fragmentary and associated with periosteal stripping, leading potentially to increased instability and vascular damage. Although creating an osteotomy improves reproducibility of the in vivo model and, in that way, keeps the number of animals used to a minimum, one could argue that there is a difference regarding the grade of stability when comparing an osteotomy and a fracture. As mechanical stability is crucial not only for fracture healing but also for infection prevention and treatment (Merritt and Dowd, 1987; Sabate Bresco et al., 2017), it seems an important parameter to include in preclinical research. Furthermore, in small animals, fixation is often performed using an intramedullary k-wire (Bilgili et al., 2015; Boyce et al., 2012; Darouiche et al., 1998; Gilbert et al., 2015; Hamel et al., 2008; Hamza et al., 2012; Helbig et al., 2015; Lesic et al., 2004; Li et al., 2009; Li et al., 2010; Lindsey et al., 2010a; Lindsey et al., 2010b; Prinz et al., 2017; Sener et al., 2010; Stewart et al., 2010; Worlock et al., 1988a; Worlock et al., 1988b; Worlock et al., 1994; Zhou et al., 2017). This will negatively impact the stability as compared to a clinical setting where more stable fixation options, e.g. locking screws, are available. Rittmann and Perren (1974), in an experimental study in sheep, show the positive effects of stability on infection in fracture care. They state that the advantage of the stabilising effect of an implant outweighs the disadvantage of a foreign body effect. Therefore, it seems important to keep in mind stability as a parameter when developing a model of an FRI, thereby focusing not only on the creation of bony instability, but also on the type of implant for fixation.

Optimally, future research should include standardised mechanical design strategies to carefully control and describe stabilisation of the construct. This would improve our ability to compare the outcome of different studies.

\section{Soft tissue damage}

A third observation was that only a minority of studies mimic soft tissue injuries $(n=19 ; 25.3 \%)$ (Table 2). These are, for the most part, also the studies where a device creates a fracture, as previously mentioned. By performing an osteotomy or creating a defect, soft tissue damage is limited to the incision and dissection needed during the surgical procedure. This does not really correspond to daily clinical practice, where fractures are often accompanied by extensive soft tissue damage, potentially causing vascular compromise or the development of haematomas. Soft tissue damage is actually one of the most important factors that influences the risk of infection (Kalicke et al., 2003; Kortram et al., 2017). For example, despite the use of systemic antibiotics, open fractures still have higher infection rates as compared to closed fractures. A reason for this is that necrotic tissue often serves as a breeding ground for bacteria that can sustain the infection. Another possible explanation is that systemic antibiotics may not reach the tissueimplant interface in high enough concentrations to eradicate bacteria due to local vascular damage. Furthermore, in cases of an FRI there is also, often, soft tissue damage (e.g. draining wounds, fistulae) (Metsemakers et al., 2018b). Therefore, translating results from preclinical in vivo work regarding, for example, new local antibiotic-delivery devices for FRI prevention or treatment should be undertaken with caution when soft tissue damage is not included.

\section{Pathogen characteristics}

$97.3 \%(n=73)$ of the 75 included models reviewed used S. aureus as the infection-causative microorganism. This might be explained by the fact that $S$. aureus is the most common single disease-causing pathogen in clinical FRIs (Torbert et al., 2015). Nonetheless, the dominance is not reflective of the clinical scenario. Although the published literature confirms that $S$. aureus is the most common disease-causing pathogen, it is responsible for only $30 \%$ of all FRIs, which is comparable to the prevalence of polymicrobial infections $(27 \%)$ and coagulasenegative staphylococci (CoNS), such as S. epidermidis (22\%). Other organisms, such as Gram-negative bacilli, are responsible for the remaining $10 \%$ 
(Trampuz and Zimmerli, 2006), but are only studied (i.e. E. coli) as a single pathogen or in combination with $S$. aureus in two of the models (Passl et al., 1984; Stewart et al., 2010). S. epidermidis can be found in only two $(2.6 \%)$ animal models, despite this microorganism having an important clinical impact due to its prevalence and widespread antimicrobial resistance (Morgenstern et al., 2016a; Morgenstern et al., 2016b). Therefore, the focus on S. aureus is understandable, but a gap of knowledge remains with regards to other pathogens in FRIs and preclinical models are not yet available to address this problem.

\section{CFU count}

The order of magnitude of the amount of inoculated bacteria varies between 1 (Costa et al., 2016) and $10^{10}$ CFU (Schaer et al., 2012). Arens et al. (2015) determine that the minimum CFU count needed to reliably cause an infection in their rabbit humeral osteotomy model is $6 \times 10^{6}$. This will likely be the optimal dose to be used in future research. However, the appropriate dose will vary depending on different parameters, such as animal selection, pathogen and implant and cannot be taken as a general inoculation guide.

\section{General considerations and conclusion}

Overall, only five $(6.7 \%)$ studies include a model that combines all key features of an FRI in one model: the presence of a fracture, delay before treatment and soft tissue damage (Boyce et al., 2012; Li et al., 2009; Li et al., 2010b; Lindsey et al., 2010b; Lindsey et al., 2010c). Although these studies only use S. aureus, they remain the models most closely recapitulating an FRI.

From an ethical standpoint it is difficult to include all the clinically important parameters in all preclinical studies. Including factors such as timing (i.e. leaving the wound open) and trauma severity (i.e. creation of a real fracture with soft tissue injury), for example, increases the burden upon the animal. Therefore, permission from an ethical approval body for such models could be more difficult to obtain. Keeping in mind that animal care is of the highest importance, interventions should be taken to minimise the load put on the animal. This could be achieved by following the 3R principles first described by Russel and Burch (1959). Since studies have failed to develop an experimental setup that could serve as a viable alternative to animal models for the research on fractures and FRIs (Auer et al., 2007), the emphasis should be placed on refinement of models that are currently being used and reducing the number of animals that is needed to obtain a comparable level of information. Refinement of current models entails the development and application of standardised anaesthesiology and pain management protocols. Adequate analgesic therapy not only reduces the burden upon the animal but might also improve the validity of the experiment (Auer et al., 2007). A reduction in the number of animals that is needed to attain an equal amount of data might be achieved by optimising the experimental setup. Nonetheless, it is difficult to define the ideal preclinical model. Hooijmans et al. (2018) adapt the Grading of Recommendations, Assessment, Development, and Evaluation (GRADE) approach (Atkins et al., 2005) for the appraisal of preclinical models. They propose a set of steps to evaluate the certainty in the evidence from preclinical animal studies. One of these steps evaluates the similarities between the described animal model and the clinical setting. Therefore, the model is compared to the research question: does the experimental setup adequately reflect the population, intervention and comparison? It seems logical that matching these populations as closely as possible (i.e. will the intervention eventually be applied in open fractures with soft tissue damage? Will a time gap be present?) will only improve the validity of the model. Thus, for animal models that should mimic the clinical setting as closely as possible, the implementation of four key characteristics is proposed: creating instability by performing a true fracture, establishing soft tissue damage, implementing a delay-to-treatment and using a pathogenic profile that approaches the clinical reality. However, not all fractures in daily clinical practice present severe soft tissue damage and certainly not all fractures are open fractures. The implementation of all the aforementioned characteristics may only be required for new strategies that are close to clinical implementation or for research questions that are likely influenced by these factors. Early stage innovations may be adequately evaluated in 'simpler' models, with comparatively less burden upon the animal, only moving to the more 'complex' models as the development cycle nears completion. Overall this means that preclinical studies should consider including parameters (e.g. soft tissue damage) that seem clinically important when focusing on prevention and treatment of FRIs without compromising the care for the animal.

In conclusion, this review demonstrated that preclinical in vivo studies rarely recreate a model of FRI that mimics all aspects of the clinical setting with creation of a fracture in combination with softtissue injury. In addition to S. aureus, the application of other clinically important pathogens and even polymicrobial infections should be considered. To really make progress in the field of prevention and treatment of FRIs, existing preclinical models should be adapted or research experts should consider developing new models to better match clinical scenarios.

\section{Acknowledgements}

The authors wish to thank the biomedical reference librarians of the KU Leuven Libraries-2Bergenlearning Centre Désiré Collen (Leuven, Belgium) 
for their help in conducting the systematic literature search.

\section{References}

Atkins D, Briss PA, Eccles M, Flottorp S, Guyatt GH, Harbour RT, Hill S, Jaeschke R, Liberati A, Magrini N, Mason J, O'Connell D, Oxman AD, Phillips B, Schunemann H, Edejer TT-T, Vist GE, Williams JWJ (2005) Systems for grading the quality of evidence and the strength of recommendations II: pilot study of a new system. BMC Health Serv Res 5: 25.

Alt V, Lips KS, Henkenbehrens C, Muhrer D, Oliveira Cavalcanti MC, Sommer U, Thormann U, Szalay G, Heiss C, Pavlidis T, Domann E, Schnettler $R$ (2011) A new animal model for implant-related infected non-unions after intramedullary fixation of the tibia in rats with fluorescent in situ hybridization of bacteria in bone infection. Bone 48: 1146-1153.

Andriole VT, Nagel DA, Southwick WO (1973) A paradigm for human chronic osteomyelitis. J Bone Joint Surg Am 55: 1511-1515.

Arens D, Wilke M, Calabro L, Hackl S, Zeiter S, Zderic I, Richards RG, Moriarty TF (2015) A rabbit humerus model of plating and nailing osteosynthesis with and without Staphylococcus aureus osteomyelitis. Eur Cells Mater 30: 148-162.

Auer JA, Goodship A, Arnoczky S, Pearce S, Price J, Claes L, von Rechenberg B, Hofmann-Amtenbrinck M, Schneider E, Muller-Terpitz R, Thiele F, Rippe K-P, Grainger DW (2007) Refining animal models in fracture research: seeking consensus in optimising both animal welfare and scientific validity for appropriate biomedical use. BMC Musculoskelet Disord 8: 72.

Azi ML, Kfuri Junior M, Martinez R, Salata LA, Jansen Paccola CA (2012) Development of an experimental model of infected bone void in the ulna of rabbits. ACTA Ortop Bras 20: 136-138.

Bi L, Hu Y, Fan H, Meng G, Liu J, Li D, Lv R (2007) Treatment of contaminated bone defects with clindamycin-reconstituted bone xenograftcomposites. J Biomed Mater Res B Appl Biomater 82: 418-427.

Bilgili F, Balci HI, Karaytug K, Sariyilmaz K, Atalar AC, Bozdag E, Tuna M, Bilgic B, Gurler N (2015) Can normal fracture healing be achieved when the implant is retained on the basis of infection? An experimental animal model. Clin Orthop Relat Res 473: 3190-3196.

Ter Boo G-JA, Arens D, Metsemakers W-J, Zeiter S, Richards RG, Grijpma DW, Eglin D, Moriarty TF (2016) Injectable gentamicin-loaded thermoresponsive hyaluronic acid derivative prevents infection in a rabbit model. Acta Biomater 43: 185-194.

Boxma H, Broekhuizen T, Patka P, Oosting H (1996) Randomised controlled trial of single-dose antibiotic prophylaxis in surgical treatment of closed fractures: the Dutch Trauma Trial. Lancet 347: 11331137.

Boyce BM, Lindsey BA, Clovis NB, Smith ES, Hobbs GR, Hubbard DF, Emery SE, Barnett JB, Li B (2012) Additive effects of exogenous IL-12 supplementation and antibiotic treatment in infection prophylaxis. J Orthop Res 30: 196-202.

Brick KE, Chen X, Lohr J, Schmidt AH, Kidder LS, Lew WD (2009) RhBMP-2 modulation of gene expression in infected segmental bone defects. Clin Orthop Relat Res 467: 3096-3103.

Brown K V, Penn-Barwell JG, Rand BC, Wenke JC (2014) Translational research to improve the treatment of severe extremity injuries. R Army Med Corps 160: 167-170.

Brown SA, Mayberry AJ, Mathy JA, Phillips TM, Klitzman B, Levin LS (2000) The effect of muscle flap transposition to the fracture site on TNF $\alpha$ levels during fracture healing. Plast Reconstr Surg 105: 991998.

Calabro L, Lutton C, Fouad Seif El Din A, Richards RG, Moriarty TF (2013) Biomaterials associated infection. Ed. TF Moriarty, SAJ Zaat, HJ Busscher. New York, Springer, pp: 273-304.

Chen XQ, Kidder LS, Lew WD (2002) Osteogenic protein-1 induced bone formation in an infected segmental defect in the rat femur. J Orthop Res 20: 142-150.

Chen X, Schmidt AH, Mahjouri S, Polly DWJ, Lew WD (2007) Union of a chronically infected internally stabilized segmental defect in the rat femur after debridement and application of rhBMP-2 and systemic antibiotic. J Orthop Trauma 21: 693-700.

Chen X, Schmidt AH, Tsukayama DT, Bourgeault CA, Lew WD (2006) Recombinant human osteogenic protein-1 induces bone formation in a chronically infected, internally stabilized segmental defect in the rat femur. J Bone Joint Surg Am 88: 1510-1523.

Chen X, Tsukayama DT, Kidder LS, Bourgeault CA, Schmidt AH, Lew WD (2005) Characterization of a chronic infection in an internally-stabilized segmental defect in the rat femur. J Orthop Res 23: 816-823.

Costa LP, Moreira Teixeira LE, Maranhao Lima GS, Ferreira MM, de Andrade MA, Teixeira Vidigal PV, Gomes Faraco AA, Temponi EF, de Araujo ID (2016) Effectiveness of chitosan films impregnated with ciprofloxacin for the prophylaxis of osteomyelitis in open fractures: an experimental study in rats. Arch Trauma Res 5: e36952. DOI: 0.5812/atr.36952.

Curtis MJ, Brown PR, Dick JD, Jinnah RH (1995) Contaminated fractures of the tibia: a comparison of treatment modalities in an animal model. J Orthop Res 13: 286-295.

Darouiche RO, Farmer J, Chaput C, Mansouri M, Saleh G, Landon GC (1998) Anti-infective efficacy of antiseptic-coated intramedullary nails. J Bone Joint Surg Am 80: 1336-1340.

De Mesy Bentley KL, Tombetta R, Nishitani K, Bello-Irizarry SN, Kates SL, Awad HA, Schwarz EM (2016) Evidence of $S$. aureus deformation, 
proliferation and migration in canaliculi of cortical bone using a murine model of osteomyelitis. J Orthop Res 34: 985-990.

Deng K, Yu A-X, Xia C-Y, Li Z-H, Wang W-Y (2013) Combination of negative pressure wound therapy with open bone grafting for bone and soft tissue defects. Mol Med Rep 8: 468-472.

Evans RP, Nelson CL, Harrison BH (1993) The effect of wound environment on the incidence of acute osteomyelitis. Clin Orthop Relat Res: 289-297.

Fei J, Yu H, Pan C, Zhao C, Zhou Y, Wang Y (2010) Efficacy of a norvancomycin-loaded, PDLLA-coated plate in preventing early infection of rabbit tibia fracture. Orthopedics 33. DOI: 10.3928/0147744720100329-06.

Gilbert SR, Camara J, Camara R, Duffy L, Waites K, Kim H, Zinn K (2015) Contaminated open fracture and crush injury: a murine model. Bone Res. 3: 14050.

Guelcher SA, Brown KV, Li B, Guda T, Lee B-H, Wenke JC (2011) Dual-purpose bone grafts improve healing and reduce infection. J Orthop Trauma 25: 477-482.

Hamel A, Caillon J, Jacqueline C, Rogez J-M, Potel G (2008) Internal device decreases antibiotic's efficacy on experimental osteomyelitis. J Child Orthop 2: 239243.

Hamza T, Dietz M, Pham D, Clovis N, Danley S, Li B (2012) Intra-cellular Staphylococcus aureus alone causes infection in vivo. Eur Cells Mater 25: 341-350.

Helbig L, Guehring T, Rosenberger S, Ivanova A, Kaeppler K, Fischer CA, Moghaddam A, Schmidmaier G (2015) A new animal model for delayed osseous union secondary to osteitis. BMC Musculoskelet Disord 16: 362.

Higgins JPT, Green S (2011) Cochrane Handbook for Systematic Reviews of Interventions. Version 5.1.0. The Cochrane Collaboration.

Hill PF, Watkins PE (2001) The prevention of experimental osteomyelitis in a model of gunshot fracture in the pig. Eur J Orthop Surg Traumatol 11: 237-241.

Hill PF, Clasper JC, Parker SJ, Watkins PE (2002) Early intramedullary nailing in an animal model of a heavily contaminated fracture of the tibia. J Orthop Res 20: 648-653.

Hooijmans CR, de Vries RBM, Ritskes-Hoitinga M, Rovers MM, Leeflang MM, IntHout J, Wever KE, Hooft L, de Beer H, Kuijpers T, Macleod MR, Sena ES, Ter Riet G, Morgan RL, Thayer KA, Rooney AA, Guyatt GH, Schunemann HJ, Langendam MW (2018) Facilitating healthcare decisions by assessing the certainty in the evidence from preclinical animal studies. PLoS One 13: e0187271. DOI: 10.1371/journal. pone.0187271.

Huang J-G, Pang L, Chen Z-R, Tan X-P (2013) Dual-delivery of vancomycin and icariin from an injectable calcium phosphate cement-release system for controlling infection and improving bone healing. Mol Med Rep 8: 1221-1227.

Inzana JA, Schwarz EM, Kates SL, Awad HA (2015) A novel murine model of established staphylococcal bone infection in the presence of a fracture fixation plate to study therapies utilizing antibiotic-laden spacers after revision surgery. Bone 72: 128-136.

Jacob E, Cierny G, Fallon MT, McNeill Jr JF, Siderys GS (1993) Evaluation of biodegradable cefazolin sodium microspheres for the prevention of infection in rabbits with experimental open tibial fractures stabilized with internal fixation. J Orthop Res 11: 404-411.

Jacob E, Cierny G, Zorn K, McNeill JF, Fallon MT (1997) Delayed local treatment of rabbit tibial fractures with biodegradable cefazolin microspheres. Clin Orthop Relat Res: 278-285.

Kalicke T, Schlegel U, Printzen G, Schneider E, Muhr G, Arens S (2003) Influence of a standardized closed soft tissue trauma on resistance to local infection. An experimental study in rats. J Orthop Res 21: 373-378.

Khodaparast O, Coberly DM, Mathey J, Rohrich RJ, Levin LS, Brown SA (2003) Effect of a transpositional muscle flap on VEGF mRNA expression in a canine fracture model. Plast Reconstr Surg 112: 171-176.

Kortram K, Bezstarosti H, Metsemakers W-J, Raschke MJ, Van Lieshout EMM, Verhofstad MHJ (2017) Risk factors for infectious complications after open fractures; a systematic review and metaanalysis. Int Orthop 41: 1965-1982.

Ktistakis I, Giannoudi M, Giannoudis P V (2014) Infection rates after open tibial fractures: are they decreasing? Injury 45: 1025-1027.

Lesic A, Bumbasirevic M, Bumbasirevic V, Krstic N, Tatic V (2004) Artificially contaminated open tibial fractures - Therapy with cloxacillin sodium. Acta Vet 54: 457-466.

Li B, Brown K V, Wenke JC, Guelcher SA (2010a) Sustained release of vancomycin from polyurethane scaffolds inhibits infection of bone wounds in a rat femoral segmental defect model. J Control Release 145: 221-230.

Li B, Jiang B, Boyce BM, Lindsey BA (2009) Multilayer polypeptide nanoscale coatings incorporating IL-12 for the prevention of biomedical device-associated infections. Biomaterials 30: 25522558.

Li B, Jiang B, Dietz MJ, Smith ES, Clovis NB, Rao KMK (2010b) Evaluation of local MCP-1 and IL-12 nanocoatings for infection prevention in open fractures. J Orthop Res 28: 48-54.

Lindsey BA, Clovis NB, Smith ES, Salihu S, Hubbard DF (2010a) An animal model for open femur fracture and osteomyelitis - part II: immunomodulation with systemic IL-12. J Orthop Res 28: 43-47.

Lindsey BA, Clovis NB, Smith ES, Salihu S, Hubbard DF (2010b) An animal model for open femur fracture and osteomyelitis: part I. J Orthop Res 28: 38-42.

Lovati AB, Drago L, Bottagisio M, Bongio M, Ferrario M, Perego S, Sansoni V, De Vecchi E, Romanò CL (2016a) Systemic and local administration of antimicrobial and cell therapies to prevent methicillin- 
resistant Staphylococcus epidermidis-induced femoral nonunions in a rat model. Mediators Inflamm 2016: 9595706.

Lovati AB, Romano CL, Bottagisio M, Monti L, De Vecchi E, Previdi S, Accetta R, Drago L (2016b) Modeling Staphylococcus epidermidis-induced nonunions: subclinical and clinical evidence in rats. PLoS One 11: e0147447.

Lubis AMT, Tobing SDL, Siregar PU (2005) The use of ceftriaxone impregnated beads in the management of chronic osteomyelitis. Med J Indones 14: 157-162.

Merritt K, Dowd JD (1987) Role of internal fixation in infection of open fractures: studies with Staphylococcus aureus and Proteus mirabilis. J Orthop Res 5: 23-28.

Metsemakers WJ, Kortram K, Morgenstern M, Moriarty TF, Meex I, Kuehl R, Nijs S, Richards RG, Raschke M, Borens O, Kates SL, Zalavras C, Giannoudis P V, Verhofstad MHJ (2018a) Definition of infection after fracture fixation: a systematic review of randomized controlled trials to evaluate current practice. Injury 49: 497-504.

Metsemakers WJ, Morgenstern M, McNally MA, Moriarty TF, McFadyen I, Scarborough M, Athanasou NA, Ochsner PE, Kuehl R, Raschke M, Borens O, Xie Z, Velkes S, Hungerer S, Kates SL, Zalavras C, Giannoudis P V, Richards RG, Verhofstad MHJ (2018b) Fracture-related infection: a consensus on definition from an international expert group. Injury 49: 505-510.

Metsemakers WJ, Schmid T, Zeiter S, Ernst M, Keller I, Cosmelli N, Arens D, Moriarty TF, Richards RG (2016) Titanium and steel fracture fixation plates with different surface topographies: influence on infection rate in a rabbit fracture model. Injury 47: 633-639.

Moher D, Liberati A, Tetzlaff J, Altman DG (2010) Preferred reporting items for systematic reviews and meta-analyses: the PRISMA statement. Int J Surg 8: 336-341.

Morgenstern M, Erichsen C, von Ruden C, Metsemakers WJ, Kates SL, Moriarty TF, Hungerer S (2016a) Staphylococcal orthopaedic device-related infections in older patients. Injury 47: 1427-1434.

Morgenstern M, Post V, Erichsen C, Hungerer S, Buhren V, Militz M, Richards RG, Moriarty TF (2016b) Biofilm formation increases treatment failure in Staphylococcus epidermidis device-related osteomyelitis of the lower extremity in human patients. J Orthop Res 34: 1905-1913.

Olesen UK, Pedersen NJ, Eckardt H, Lykke-Meyer L, Bonde CT, Singh UM, McNally M (2017) The cost of infection in severe open tibial fractures treated with a free flap. Int Orthop 41: 1049-1055.

Papakostidis C, Kanakaris NK, Pretel J, Faour O, Morell DJ, Giannoudis P V (2011) Prevalence of complications of open tibial shaft fractures stratified as per the Gustilo-Anderson classification. Injury 42: 1408-1415.
Passl R, Muller C, Zielinski CC, Eible MM (1984) A model of experimental post-traumatic osteomyelitis in guinea pigs. J Trauma 24: 323-326.

Penn-Barwell JG, Murray CK, Wenke JC (2012a) Early antibiotics and debridement independently reduce infection in an open fracture model. J Bone Joint Surg Br 94: 107-112.

Penn-Barwell JG, Rand BCC, Brown K V, Wenke JC (2014a) A versatile model of open-fracture infection : a contaminated segmental rat femur defect. Bone Joint Res 3: 187-192.

Penn-Barwell JG, Baker B, Wenke JC (2015) Local bismuth thiols potentiate antibiotics and reduce infection in a contaminated open fracture model. J Orthop Trauma 29: e73-e78.

Penn-Barwell JG, Murray CK, Wenke JC (2012b) Comparison of the antimicrobial effect of chlorhexidine and saline for irrigating a contaminated open fracture model. J Orthop Trauma 26: 728-732.

Penn-Barwell JG, Murray CK, Wenke JC (2014b) Local antibiotic delivery by a bioabsorbable gel is superior to PMMA bead depot in reducing infection in an open fracture model. J Orthop Trauma 28: 370375.

Petri WH, Schaberg SJ (1984) The effects of antibiotic-supplemented bone allografts on contaminated, partially avulsive fractures of the canine ulna. J Oral Maxillofac Surg 42: 699-704.

Prinz C, Elhensheri M, Rychly J, Neumann H-G (2017) Antimicrobial and bone-forming activity of a copper coated implant in a rabbit model. J Biomater Appl 32: 139-149.

Rand BCC, Penn-Barwell JG, Wenke JC (2015) Combined local and systemic antibiotic delivery improves eradication of wound contamination: an animal experimental model of contaminated. Bone Jt J 97-B: 1423-1427.

Reizner W, Hunter JG, O'Malley NT, Southgate RD, Schwarz EM, Kates SL (2014) A systematic review of animal models for Staphylococcus aureus osteomyelitis. Eur Cells Mater 27: 196-212.

Rittmann W, Perren S (1974) Cortical bone healing after internal fixation and infection. Berlin: Springer.

Robinson DA, Bechtold JE, Carlson CS, Evans RB, Conzemius MG (2011) Development of a fracture osteomyelitis model in the rat femur. J Orthop Res 29: 131-137.

Rochford ETJ, Sabate Bresco M, Zeiter S, Kluge K, Poulsson A, Ziegler M, Richards RG, O'Mahony L, Moriarty TF (2016) Monitoring immune responses in a mouse model of fracture fixation with and without Staphylococcus aureus osteomyelitis. Bone 83: 82-92.

Russell W, Burch R (1959) The principles of humane experimental technique. London: Methuen.

Sabate Bresco M, O’Mahony L, Zeiter S, Kluge K, Ziegler M, Berset C, Nehrbass D, Richards RG, Moriarty TF (2017) Influence of fracture stability on Staphylococcus epidermidis and Staphylococcus aureus infection in a murine femoral fracture model. Eur Cell Mater 34: 321-340. 
Sanchez CJJ, Prieto EM, Krueger CA, Zienkiewicz KJ, Romano DR, Ward CL, Akers KS, Guelcher SA, Wenke JC (2013) Effects of local delivery of D-amino acids from biofilm-dispersive scaffolds on infection in contaminated rat segmental defects. Biomaterials 34: 7533-7543.

Schaer TP, Stewart S, Hsu BB, Klibanov AM (2012) Hydrophobic polycationic coatings that inhibit biofilms and support bone healing during infection. Biomaterials 33: 1245-1254.

Schindeler A, Yu NYC, Cheng TL, Sullivan K, Mikulec K, Peacock L, Matthews R, Little DG (2015) Local delivery of the cationic steroid antibiotic CSA90 enables osseous union in a rat open fracture model of Staphylococcus aureus infection. J Bone Joint Surg Am 97: 302-309.

Seebach E, Holschbach J, Buchta N, Bitsch RG, Kleinschmidt K, Richter W (2015) Mesenchymal stromal cell implantation for stimulation of long bone healing aggravates Staphylococcus aureus induced osteomyelitis. ACTA Biomater 21: 165-177.

Sener M, Kazimoglu C, Karapinar H, Gunal I, Afsar I, Karatas Sener AG (2010) Comparison of various surgical methods in the treatment of implantrelated infection. Int Orthop 34: 419-423.

Sethi S, Thormann U, Sommer U, Stotzel S, Mohamed W, Schnettler R, Domann E, Chakraborty T, Alt V (2015) Impact of prophylactic CpG oligodeoxynucleotide application on implantassociated Staphylococcus aureus bone infection. Bone 78: 194-202.

Southwood LL, Frisbie DD, Kawcak CE, Ghivizzani SC, Evans CH, McIlwraith CW (2004) Evaluation of Ad-BMP-2 for enhancing fracture healing in an infected defect fracture rabbit model. J Orthop Res 22: 66-72.

Srour M, Inaba K, Okoye O, Chan C, Skiada D, Schnuriger B, Trump M, Lam L, Demetriades D (2015) Prospective evaluation of treatment of open fractures: effect of time to irrigation and debridement. JAMA Surg 150: 332-336.

Stewart RL, Cox JT, Volgas D, Stannard J, Duffy L, Waites KB, Chu T-M (2010) The use of a biodegradable, load-bearing scaffold as a carrier for antibiotics in an infected open fracture model. J Orthop Trauma 24: 587-591.

Stewart S, Barr S, Engiles J, Hickok NJ, Shapiro IM, Richardson DW, Parvizi J, Schaer TP (2012) Vancomycin-modified implant surface inhibits biofilm formation and supports bone-healing in an infected osteotomy model in sheep: a proof-ofconcept study. J Bone Joint Surg Am 94: 1406-1415.

Tennent DJ, Shiels SM, Sanchez CJJ, Niece KL, Akers KS, Stinner DJ, Wenke JC (2016) Time-dependent effectiveness of locally applied vancomycin powder in a contaminated traumatic orthopaedic wound model. J Orthop Trauma 30: 531-537.

Torbert JT, Joshi M, Moraff A, Matuszewski PE, Holmes A, Pollak AN, O'Toole R V (2015) Current bacterial speciation and antibiotic resistance in deep infections after operative fixation of fractures. J Orthop Trauma 29: 7-17.

Trampuz A, Zimmerli W (2006) Diagnosis and treatment of infections associated with fracturefixation devices. Injury 37 Suppl 2: S59-66.

Tran N, Tran PA, Jarrell JD, Engiles JB, Thomas NP, Young MD, Hayda RA, Born CT (2013) In vivo caprine model for osteomyelitis and evaluation of biofilm-resistant intramedullary nails. Biomed Res Int 2013: 674378 .

Windolf CD, Logters T, Scholz M, Windolf J, Flohe S (2014) Lysostaphin-coated titan-implants preventing localized osteitis by Staphylococcus aureus in a mouse model. PLoS One 9: e115940.

Windolf CD, Meng W, Logters TT, MacKenzie CR, Windolf J, Flohe S (2013) Implant-associated localized osteitis in murine femur fracture by biofilm forming Staphylococcus aureus: a novel experimental model. J Orthop Res 31: 2013-2020.

Worlock P, Slack R, Harvey L, Mawhinney R (1988a) An experimental model of post-traumatic osteomyelitis in rabbits. Br J Exp Pathol 69: 235-244.

Worlock P, Slack R, Harvey L, Mawhinney R (1988b) The prevention of infection in open fractures. An experimental study of the effect of antibiotic therapy. J Bone Joint Surg Am 70: 1341-1347.

Worlock P, Slack R, Harvey L, Mawhinney R (1994) The prevention of infection in open fractures: an experimental study of the effect of fracture stability. Injury 25: 31-38.

Xiao W, Luo S-H, Wei X-JX-J, Zhang C-Q, Huang W-H, Chen J-K, Cai Y, Rui Y, Rahaman MN (2015) Evaluation of Ti implants coated with Ag-containing borate bioactive glass for simultaneous eradication of infection and fracture fixation in a rabbit tibial model. J Mater Res 30: 3147-3156.

Xie Z-P, Zhang C-Q, Yi C-Q, Qiu J-J, Wang J-Q, Zhou J (2009) In vivo study effect of particulate Bioglass ${ }^{\circledR}$ in the prevention of infection in open fracture fixation. J Biomed Mater Res B Appl Biomater 90: 195-201.

Zheng Z, Yin W, Zara JN, Li W, Kwak J, Mamidi R, Lee M, Siu RK, Ngo R, Wang J, Carpenter D, Zhang X, Wu B, Ting K, Soo C (2010) The use of BMP-2 coupled - Nanosilver-PLGA composite grafts to induce bone repair in grossly infected segmental defects. Biomaterials 31: 9293-9300.

Zhou L, Liu Q, Zhou Z, Lu W, Tao J (2017) Efficacy of tobramycin-loaded coating K-wire in an openfracture rabbit model contaminated by Staphylococcus aureus. Int J Clin Exp Med 10: 6004-6016.

\section{Discussion with Reviewers}

Stephen Kates: What models should be used for small and large animals to study infection effectively? What is the appropriate mechanism of injury and animal model to replicate the human condition?

Authors: There is currently insufficient evidence for 
preferring any single animal species over another. Several factors must be considered when making this decision. It seems logical to base the choice of animal on the objective of the study. Large animals, where human implants and human scale interventions can be used, could be favourable for studying mechanical factors, while small animals, such as rodents, are better suited for investigating molecular mechanisms and genetics of bone healing (Auer et al., 2007). Biology is a factor but, currently, the immune response to FRIs in the different animal species is only poorly understood. Within this respect, mice might be the best understood species, but this certainly does not mean that they are the closest resemblance to humans. Additionally, cost will have a large impact, which favours the use of smaller animals. To increase the value of the research, models using both small and large animals should include the key characteristics of an FRI: a real fracture, soft tissue damage, a time gap and a diversity in pathogens. Currently, the specific tools to produce some of these key characteristics are mainly available for mice, rats, rabbits and sheep. Thus, all these species are good options for future research.

The appropriate mechanism of injury is presumably the creation of a traumatic fracture. This could, for example, be done by means of dropping a weight. In addition to creating a more realistic fracture, this type of injury will also incorporate soft tissue damage.

Stephen Kates: What about the closed fracture that is opened for surgical repair and becomes infected? Authors: Clinically, the risk of infection after closed fractures is less frequent as compared to open fractures, but it would also be an interesting study topic. Theoretically, these infections are seeded at the time of (or shortly after) the primary surgical procedure. Therefore, preclinical models studying these infections will require inoculation at the time of surgery or with a short delay. The used pathogen should be selected based on the clinical scenario that aims at reproducing. However, soft tissue damage can be limited and there is no need for a time gap between injury and treatment, which will make these models also less of a burden for the experimental animals.

Volker Alt: Would you prefer an osteotomy or a fracture model for preclinical testing?

Authors: When choosing between these two models, two factors should be considered. Since fracture stability influences infection, the chosen model should ideally mimic daily clinical practice. In clinical practice adequate fixation is harder to achieve in case of a fracture as compared to the use of an osteotomy. On the other hand, instability should be reproducible when applied to multiple animals. This is of course easier in case of an osteotomy. Therefore, in theory, the optimal method would be a reproducible fracture model, which is currently difficult to achieve.
Volker Alt: Which microorganisms and, in case of polymicrobial approaches, which combinations should be used more often besides $S$. aureus in FRI models?

Authors: Preclinical models should reflect the diversity in pathogens found in a clinical setting. Trampuz and Zimmerli (2006) display the heterogeneity of infection-causing pathogens. While $S$. aureus is still responsible for a substantial part of all infections, researchers should not solely focus on this microorganism. Instead, they should consider other bacteria that have a nearly similar share in causing FRIs. Several studies show the important contribution of S. epidermidis (Sabate Bresco et al., 2017; Trampuz and Zimmerli, 2006). However, this fact is currently not reflected in research setups. In addition, considering the recent increase in infections caused by multidrug-resistant germs, these should also play a vital role in modern study setups.

The appropriate combinations of microorganisms for the research on polymicrobial approaches are more difficult to define, since evidence concerning this subject is limited. Available clinical studies show that the following bacterial species are often involved in polymicrobial infections: $S$. aureus, $P$. aeruginosa, A. baumannii and Enterococcus species (Jorge et al., 2018, additional reference).

Volker Alt: What is the objective benefit of FRI models including all 3 key features of open fractures? In other words: is there experimental evidence to adapt preclinical models to clinical FRIs by delay before treatment and tissue damage, especially behind the background of the $3 \mathrm{R}$ principles?

Authors: Separate independent studies show that each of these key features individually impact the infection (Kalicke et al., 2003; Kortram et al., 2017; Worlock et al., 1994). In clinical cases, all of these factors are often present. One of the proposed grading scales to evaluate the adequacy of an experimental setup is the modified GRADE scale (Hooijmans et al., 2018). In one of the steps of this scale, the comparability between the animal model and the research question is examined. Therefore, matching the experimental setup as closely as possible to the clinical setup, by implementing these features, would increase the value of the gathered evidence from these models.

David Grainger: Can the authors comment about the experimental approaches to produce polymicrobial infections in these preclinical models, as they might be more comparable to clinical FRIs? What are the best practices?

Authors: Only three (4\%) of the 75 studies that were included in this systematic review describe a model in which a polymicrobial infection is studied. This number is very low in comparison to the $27 \%$ occurrence of polymicrobial infections in a clinical setting (Trampuz and Zimmerli, 2006), suggesting further study on polymicrobial infection is warranted. 
Gilbert et al. (2015) inoculate the fracture with a saline solution containing $1 \times 10^{5} \mathrm{CFU}$ of $A$. baumannii and $1 \times 10^{4} \mathrm{CFU}$ of MRSA. Bacterial burden is assessed after 1, 2 and 4 weeks. MRSA is found in all cultures at all time points. A. baumannii is detected in only half of the specimens at week one and in none by the fourth week. Petri and Schaberg (1984) inject the fracture site with an inoculum containing $5 \times 10^{6} \mathrm{CFU}$ of $S$. aureus and $5 \times 10^{6} \mathrm{CFU}$ of $P$. aeruginosa. Bacterial burden is not routinely investigated. However, cultures from wound exudate of five animals are all positive for P. aeruginosa. S. aureus is found in three of the samples. Stewart et al. (2010) inoculate the fracture with a solution containing $S$. aureus at $1 \times 10^{6} / \mathrm{mL}$ and $E$. coli at $1 \times 10^{4} / \mathrm{mL}$. Culture results are highly variable, with only one animal testing positive for $E$. coli. These combinations match the combinations that are classically found in a clinical setting (Jorge et al., 2018, additional reference). While it seems evident that more research should include polymicrobial infections, it is currently difficult to provide best practices in terms of how the inoculum should be administered to achieve a true polymicrobial infection or how to assess relative abundance of different species over time. The interactions between different pathogen in FRI wounds and in biofilms is a highly pertinent topic and further research is required to more closely study this important clinical phenomenon.

\section{Additional Reference}

Jorge LS, Fucuta PS, Oliveira MGL, Nakazone MA, de Matos JA, Chueire AG, Salles MJC (2018) Outcomes and risk factors for polymicrobial posttraumatic osteomyelitis. J Bone Jt Infect 3: 20-26.

Editor's note: The Scientific Editor responsible for this paper was Chris Evans. 